\title{
Mediatic, Informational and Digital Skills and Competencies in Students from Agricultural Family Schools and Rural Family Home, in the Amazon Biome, Brazil
}

\author{
Tércia Zavaglia Torres' ${ }^{1}$, Marcia Izabel Fugisawa Souza1, Luiz Manoel Silva Cunha ${ }^{1}$, \\ José Ruy Porto de Carvalho' ${ }^{1}$, Jaudete Daltio², João Alfredo Carvalho Mangabeira² \\ ${ }^{1}$ Embrapa Agricultural Informatics, Campinas, SP, Brazil \\ ${ }^{2}$ Embrapa Territorial, Campinas, SP, Brazil \\ Email: tercia.torres@embrapa.br, marcia.fugisawa@embrapa.br, luiz.cunha@embrapa.br, jaudete.daltio@embrapa.br, \\ joao.mangabeira@embrapa.br
}

How to cite this paper: Torres, T. Z., Souza, M. I. F., Cunha, L. M. S., de Carvalho, J. R. P., Daltio, J., \& Mangabeira, J. A. C. (2020). Mediatic, Informational and Digital Skills and Competencies in Students from Agricultural Family Schools and Rural Family Home, in the Amazon Biome, Brazil. Creative Education, 11, 1469-1496. https://doi.org/10.4236/ce.2020.118107

Received: June 24, 2020

Accepted: August 25, 2020

Published: August 28, 2020

Copyright $\odot 2020$ by author(s) and Scientific Research Publishing Inc. This work is licensed under the Creative Commons Attribution International License (CC BY 4.0).

http://creativecommons.org/licenses/by/4.0/ (c) (i) Open Access

\begin{abstract}
The article presents partial results of an ongoing research action, within the scope of the project "Geodigital Inclusion and Territorial Management of Family-Based Production Units: Generation of Sustainability Index for the Amazon Biome". This project provides for the definition and availability of indicators of environmental, economic, agricultural, social and governance sustainability, aiming to assist family farmers in the management of the property, subsidizing them in decision making and increasing family income. Embrapa Territorial Intelligence carries out the execution of this research project in partnership with Embrapa Agricultural Informatics, units of the Brazilian Agricultural Research Corporation (Embrapa), headquartered in Campinas, São Paulo (SP), Brazil. The article presents a contribution to the education of the field in Brazil, through a continuous formation action, in the non-formal education modality, through presential and distance training courses, for students of the Agricultural Family School (EFA acronym for which it is known in Brazil) and Rural Family House (CFR acronym for which it is known in Brazil) in the Amazon Biome. This action was based on a training needs diagnosis, conducted through a questionnaire applied to 144 students, distributed between EFA and CFR, located in the Brazilian states of Acre, Amapá, Maranhão, Mato Grosso, Pará, Rondônia and Roraima. The objective of this diagnosis was to identify and analyze the training needs regarding: 1) media, informational and digital skills and competencies of these students; 2) students' level of knowledge and domain of issues related to agricultural production systems and the sustainable development of family
\end{abstract}


agricultural production units. This paper analyzes and presents the result of the diagnosis regarding only the students' media, informational and digital skills and competencies. In this sense, the analysis of these competencies provided the subsidies for the elaboration of a formation and qualification program, oriented under the Pedagogy of Alternance approach, and that considers the specificities and the aspirations of the young students, in search of an education of the field compatible with the local reality and the aspiration of the subjects involved in the process.

\section{Keywords}

Non-Formal Education, Training, Diagnosis of Skills and Competencies, Education of the Field, Pedagogy of Alternance

\section{Introduction}

The concepts and guidelines formulating media and information literacy (MIL) (Grizzle \& Calvo, 2016) provided the guiding principles for the conception of an action proposal for training young people, mostly students from Agricultural Family School (EFA acronym for which it is known in Brazil) and Rural Family House (CFR acronym for which it is known in Brazil), in the Amazon Biome, which comprises the states of Acre, Amapá, Amazonas, Maranhão, Mato Grosso, Rondônia and Roraima. MIL is understood as the capacity that is developed by/in people to access, produce and distribute information and media content in various formats and various digital tools (UNESCO, 2013). Gaps in the development of these skills and competencies in people indicate that (Grizzle \& Calvo, 2016: pp. 12-13):

[...] probably, the disparities between those who have and those who do not have access to information and the media, and between those who exercise or not freedom of expression, will increase. [...] between those who are and those who are not able to find, analyze and evaluate critically, in addition to applying information and media content in decision making. The new media and information technologies, while offering more opportunities and new types of citizen involvement with a focus on freedoms and the eradication of inequalities, also raise [...] the need to empower or protect citizens and local and global cultural interests, which threaten to reduce freedom of expression and the appreciation of cultural diversity, multilingualism and pluralism.

Media and information literacy (MIL) is a concept that encompasses media literacy and information literacy, along with information and communication technologies (ICT) and digital literacy. MIL is considered the foundation of a new literacy construct, which encourages the participation and empowerment of people, communities and nations towards the construction of the knowledge so- 
ciety (UNESCO, 2013: p. 17):

The adoption of MIL concepts in student training action meets the needs of promoting greater access, convergence and distribution of information and media and digital content, under different formats and tools. Therefore, it is understood that: MIL helps develop critical thinking and problem solving, while increasing collaboration and participation. [...] A person literate in media and information should not only be a consumer of information and media content, but also a responsible information seeker, knowledge creator and innovator, who is able to take advantage of a diverse range of information and communication and media tools.

In this context, the contribution of the Brazilian Agricultural Research Corporation (Embrapa) to education of the field is inserted, through training actions

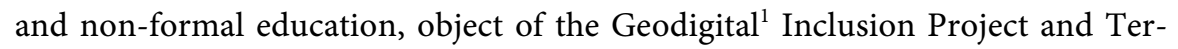
ritorial Management of Family Based Production Units: Generation of sustainability index for the Amazon Biome, called the IGGTS Project. This project is financed by the Amazon Fund through the Brazilian Development Bank of Brazil (BNDES). The emphasis of the research developed in the project is centered on strengthening the autonomy of the communities involved in the social inclusion process itself, based on educational activities and practices supported by ICT.

In turn, the proposed training action for students is conceived from the understanding of the context of education of the field, especially of education of the field in the Amazon, as well as an understanding of the logic of Pedagogy of Alternance as a teaching organization methodology adopted in the EFA and CRF in the Amazon Biome. It is a proposal for a face-to-face and distance training action, which aims to offer learning opportunities based on didactic-pedagogical content, designed under the principles of MIL, in addition to being associated with sustainable development concepts applied to the family production unit. Through geodigital inclusion actions, it is expected that opportunities will be created for local agents, development agents and family farmers to establish new levels of social organization, making it possible to reconcile productivity, conservation of natural resources and social equity.

This article is structured as follows: the second section articulates the issue of digital inclusion for sustainable development inherent in the IGGTS Project to the concepts of MIL and ICT in education of the field. The third section addresses the struggles for the right to land, followed by the incorporation of the issue of the right to education. Briefly, it analyzes education of the field in the Amazon, relating it to the enormous specificities and particularities that must be understood by those who wish to propose educational and training actions, as presented below. Section four is devoted to Pedagogy of Alternance, its origins and its predominance in Brazil, as a teaching and school organization methodology practiced in EFA and CFR. Section five presents the methodology ${ }^{1}$ Geodigital refers to the set of information and geospatial technologies related to social, environmental, economic and territorial dynamics. 
adopted for diagnosing skills/competencies in MIL of young people who are part of the EFA and CFR of the Amazon Biome, the public to be benefited from the training actions of the IGGTS Project. The sixth section is dedicated to the presentation of the results of the diagnostic, followed by the conclusions, exposed in the seventh section.

\section{Geodigital Inclusion for Sustainable Development: Media and Information Skills and Use of Digital Technologies in Education of the Field}

There is a growing convergency of economic, social and pedagogical aspects due to the increase in ICT in education, especially with regard to literacies (media, information, and digital), considered essential for contemporary life, both for work and for free time (Organización para la Cooperación y Desarollo Econômico, 2003). Media and information competency involve a range of capacities and skills necessary for the full exercise of educational and socio-cultural expressions and manifestations in any media, as well as aspects related to the critical use of products and services based on digital technologies. In this context, the definition of MIL is inserted as "[...] the ability to access, analyze and evaluate the power of images, sounds and messages that confront the contemporary subject as well as to communicate in a competent way" (Borges, 2014). MIL brings the need for reflection on the capacities and skills that individuals need to acquire in order to "[...] produce and critically consume media content. That is, as important as paying attention to messages and analyzing them, is knowing how to express yourself critically and consciously in the new media" (Guida, Borges, \& Sigiliano, 2017: p. 699).

With the IGGTS Project, the Embrapa contributes to education of the field, through training and non-formal education actions. In addition, it develops a technological solution for territorial management capable of generating sustainability multi-criteria indexes, with a view to empowering youth and rural families, and community leaders and multipliers of sustainable development practices. This project uses information geotechnologies to promote geodigital inclusion, especially with regard to economic, environmental, social, agronomic and governance assessment, based on sustainability index.

Geodigital inclusion in rural areas promotes the democratization of information, offering possibilities of socioeconomic and environmental advantages for the farmers involved and surrounding communities. With the information obtained more quickly, with higher quality and in an interactive way, the community of family farmers will be able to organize themselves better, reflecting and acting proactively and critically in solving the identified problems.

\section{Education of the Field in Brazil}

In Brazil, since the last decades of the twentieth century, social and union movements in the field have been involved in a broad process of struggle for the 
guarantee of access rights to land, including other social demands, such as education (Prazeres, 2013). These movements and social organizations, representative of the rural working class, especially in the Amazon, are basically made up of family farmers, settled workers, campers and paid rural workers, extractivists, artisanal fishermen, riverine people, forest people, traditional communities and quilombolas. These social actors are the active protagonists of "[...] disputes related to the conquest of land, fishing territories and the forest, the strengthening of family-based agriculture and the guarantee of a dignified life [...] in which it is included the right to education" (Hage \& Cardoso, 2013: p. 426).

With regard to education of the field, the Landless Rural Workers' Movement (MST) was a pioneer in launching in 1977 the premises that would support social movements in favor of education of the field (Ferreira Sobrinho, 2013). It is undeniable that initiatives like the one mentioned have triggered a set of organized social movements to promote the debate on education of the field. As an example, we can mention the consolidation of the Field Education Movement, organized at national level, as well as the Paraense Field Education Movement, together with the Paraense Forum of Field Education, in the Pará state (Hage \& Cruz, 2015; Pereira, 2017).

The Field Education Movement emerged in the context of the 1st Meeting on Education in the Rural Area, which represented a historical landmark for the contributions presented for the analysis of the education of the peoples of the countryside, problematizing the reality of field schools. This Movement was essential for criticizing the concept of education centered on the urban perspective, "[...] in the transplantation of technologies and educational methods and urban content for the rural context, inefficient materials and basic structure for the functioning of schools and disrespect for local culture" (Vasconcelos, 2017: p. 100).

Numerous other historical events were organized by social movements, public subjects and collective actors, engaged in the discussion, elaboration and proposition of inclusive actions for the Amazon field, seeking to guarantee access to an education that conceives workers as rights owners. That is, an education aimed at people living in the countryside, whose pedagogical and methodological essence is capable of reflecting the identities of the countryside's individuals (Prazeres, 2013). From these efforts, relevant contributions stood out, culminating in the constitution of what is currently called education of the field (Hage \& Cruz, 2015; Prazeres, 2013; Vasconcelos, 2017).

In Brazil, education of the field finds legal support through decree, laws, ordinance, opinion and resolutions of the National Education Council. Education of the field contrasts with rural education which (Vasconcelos, 2017: p. 127): "[...] served as a basis both for criticizing the reality of the peoples of rural territories [...] and for asserting power instituted with the development of homogenizing and assistentialist policies [...]. Still on education of the field (Vasconcelos, 2017: p. 126), it is mentioned that:

[...] the experiences that contribute to thinking education of the field as a 
new paradigm of Education based on Pedagogy of the Movement, Pedagogy of the Oppressed and Popular Education, are those that start from the evaluation of public policies to serve either the settlers, the riverine people, the teachers [...], or those who start from the analysis of Pedagogy of Alternance and its relationship with Amazonian sustainability carried out in Amazonas [...].

It is worth highlighting the existence of an inclusive perspective of education of the field that, in view of the specificities, the locations, the Amazonian culture and the different realities of the rural workers, moves towards the construction of alternatives against hegemonic in terms of education.

\section{Education of the Field in the Amazon}

The Amazon, despite its vast cultural wealth, expressed "[...] in the legends, dances and stories that make up the socio-cultural imaginary of rural and riverside populations", continues to have this wealth "[...] ignored by the urban culture that gradually deconstructs and devalues the imagination of rural and riverside populations" (Prazeres \& Carmo, 2011: p. 9). Hence the need to understand education of the field in the Amazon from the perspective of trade union movements (Campos, 2016), considering it as a strategy to keep the countryside man in his place of origin, in the coexistence of his family, guaranteeing his way of life, without needing to be expelled to the city in search of a job.

In this sense, it is up to the State, in particular, to public education policies, to fully incorporate the historical conditions of the Amazonian peoples, based on the understanding that education is intertwined in the daily dynamics of the countryside peoples, in which the values, the way of life and the feeling of belonging to the place are reaffirmed (Campos, 2016). Regarding the scenario and challenges of education of the field in Brazil and in the Amazon, although there have been significant advances under Brazilian law (Prazeres \& Carmo, 2012: p. 383 ) “[...] these have not been sufficient to affirm education in/of the field".

\section{Pedagogy of Alternance}

Pedagogy of Alternance is so named because it works with a school calendar structured in alternations, in an inseparable relationship between school time and community time. From the perspective of Pedagogy of Alternance, work is seen as an educational principle (Cordeiro, Reis, \& Hage, 2011). Through this pedagogical and methodological proposal, the authors argue, young farmers have the possibility to continue their studies and have access to technical and scientific knowledge, based on the problematization of their reality and daily lives. The alternation in schools of the field is characterized as follows (Silva, Gomes, \& Wanzeler, 2007: p. 117):

School time is characterized by the period that students get together to study in the classroom, getting in touch with the contents of the subjects offered to them, thus having the opportunity to see and build new know- 
ledge; while community time is a complementary part of school time, being the moment when students are builders of their own knowledge, as they carry out research according to the thematic axes proposed in the alternations.

In the context of Pedagogy of Alternance, young students have the opportunity to break with the idea that the countryside represents the place of backwardness and devaluation of their culture and knowledge. On the contrary, they begin to recognize the true value of their daily experiences, of their forms of organization, whether in the cultural sphere or in the production process (Silva, Gomes, \& Wanzeler, 2007).

\subsection{Origins of Pedagogy of Alternance}

Pedagogy of Alternance emerged in France, in the 1930s, from the peasants' reflections on the harsh reality to which they were subjected, given the difficult economic and social conditions of the time, mainly in agriculture (Zimmermann, Venduscolo, \& Dorneles, 2013). On the parents' part, there was a great concern in keeping their children as their successors in the agricultural activity. There were also strong pressures for economic and social changes, including in the field, which required the employment of the youth workforce in agricultural activities. On the other, young people to continue their studies would have to abandon their families and the countryside, leaving for the city in search of training (Zimmermann, Venduscolo, \& Dorneles, 2013).

From these concerns, farmers together with the parish priest in the community began to discuss possibilities for young people to continue studying, without having to leave their families and the field. Faced with discontent with the field school and the need for their children's workforce to conduct work on family properties, collectively they decided that young people should stay "[...] in the priest's house for some days of the month, studying full time, and in the others, they would be in their homes, continuing their education (Zimmermann, Venduscolo, \& Dorneles, 2013: p. 80).

Hence the form of learning is based on the alternating of school times, in which the youngster should spend a week in the church's accommodation and two weeks in the family property. The young person's time in the church would be dedicated to educational activities; and the young person's time on the property with his family would be used to observe the reality, gathering information, analyzing the problems detected in the community and by the family. Upon returning to the church accommodation to attend school time, the youngers would seek to socialize the experiences and difficulties observed in the family property and in the community, and in this exercise would seek answers and possible solutions to the problems encountered.

In this context, the State, the private sector and farmers, especially parents, were involved, giving rise to the educational alternation modality (Cordeiro, Reis, \& Hage, 2011: p. 117) “[...] representing a new educational project with the 
insertion of knowledge from French agriculture". As a result of these articulation efforts, the first Maison Familiale Rurale (MFR) was created, constituting the birth of the first school of Pedagogy of Alternance, and from then on, teaching possibilities were created to serve the children of French peasants and keep them in the field (Vizolli, Aires, \& Barreto, 2018).

Since then, the Maison Familiale Rurale (MFR), in Brazil called Rural Family House (CFR), has been structuring didactically and methodologically and expanding on several continents, in addition to countries like France, Italy and Portugal. In Latin America, in 1969, Brazil is the pioneer in the application of the methodology and experience of teaching based on alternation, created by MFR.

\subsection{Pedagogy of Alternance in Brazil: Agricultural Family School (EFA) and Rural Family House (CFR)}

The pioneering Brazilian experiences in school education through Pedagogy of Alternance were conducted by these two distinct types of institutions, and under inspiration and guidance in the Italian model (Prazeres, 2013). These experiences were led by the Maisons Familiales Rurales Movement in Brazil with the implementation of EFAs, in Espírito Santo, in 1969, and managed by the Agricultural Family School of Brazil (Unefab); and the CFRs, in Paraná, in 1987, managed by the Regional Association of Rural Family Houses (Arcafar).

Currently, Brazilian institutions that adopt Pedagogy of Alternance as a school teaching methodology form a network made up of Agricultural Family Schools (EFAs) and Rural Family Houses (CFRs). The performance of EFAs and CFRs, analyzed from the perspective of Pedagogy of Alternance, is attuned to meeting the specificities of rural reality, identified with the actors involved in education of the field, especially in relation to the desires of the youngers and their families to feel included and participating in this process. Pedagogy of Alternance has contributed to the emergence of alternatives for survival for young students, opening new horizons of action and envisioning possibilities for field work, whether in the family property or in the agricultural community.

In addition, as a methodological proposal for school education, Pedagogy of Alternance has the merit of establishing a dialogical relationship between the tacit knowledge that the youngers brings from their family and communities and the scientific knowledge built in the EFAs and CFRs (Esteves, Freiria, Alves, \& Garcia, 2017).

\section{Methodology}

For the development of the research reported in this article, the descriptive research method was adopted, which is based on the analysis, recording, description and correction of facts and phenomena without manipulating them (Garces, 2010). The choice of this method is justified because it allows the discovery of the characteristics and establishes relationships about the knowledges, knowledge, skills, and experiences of the research subjects. Research subjects are 
students from EFA and CFR located in the states of Acre, Amapá, Maranhão, Mato Grosso, Pará, Rondônia and Roraima in the Brazilian Amazon Biome. The chosen methodology allows characterizing and revealing the relationships of the subjects regarding: use of digital media as a space for discourse production; political use of language (Côrbo \& Gonçalves, 2015); human socialization; the creation on new skills and learning among people; and, building citizenship (Mello, Souza, \& Torres, 2017). In other words, social media produce meanings, knowledge and senses and reverberate the rationalities inherent to certain groups of people who are subject to the same socioeconomic and cultural conditions.

Among the types of descriptive research, the diagnosis was chosen, which consists of conducting a survey of data and information directly collected from the students. Diagnosis is a type of research that helps to define alternatives to support the decision-making process in relation to a given issue. In the case of this article, the diagnosis made will subsidize the elaboration of a formation and capacitation program, guided by the Pedagogy of Alternance approach, which considers the local reality and the aspiration of the individuals involved in the process.

The diagnosis made was preceded by the following steps:

* Step 1: Survey and bibliographic review that consisted of searching, reading and analyzing bibliographic material about: media, informational and digital literacy; education of the field; education of the field in Brazil; education of the field in the Amazon; Pedagogy of Alternance; and use of digital technologies in education of the field.

* Step 2: Elaboration and application of the data collection instrument, which consisted of a closed questionnaire with two types of questions: multiple choice questions with an alternative to one or more answers per respondent; and questions based on a four-point scale. The questionnaire contained three parts.

Part 1: Characterization of the target audience, in which information about the identification, gender, age group, state and city where they live and the level of education of the students was raised.

Part 2: Skills in digital literacy, dedicated to identifying students' ability to access, produce and distribute information and media content in various formats and different digital tools (UNESCO, 2003). The digital technologies used in their professional and school activities were identified, as well as their digital skills/competencies for using computers, web contents, media and information necessary to perform basic tasks. It was also identified how much they use the main skills/competencies and how much they domain them.

Part 3: Conceptual skills that students have on issues related to sustainable territorial development and management. The questionnaire presented a set of concepts, definitions and knowledge necessary to understand and use sustainable development indexes in the properties. It was also to identify the degree of importance that students give to concepts, definitions and knowledge considered necessary and how much they dominate them. It should be noted that the data 
referring to Step 3 of the questionnaire will not be analyzed in this article.

During the elaboration phase of the data collection instrument the questionnaire was generated, which was properly adjusted and validated before starting the actual collection. The instrument was applied in the municipalities of: Acrelândia (AC); Macapá (AP), São Luiz (MA), Juína (MT), Marabá (PA), Ji-Paraná (RO) and Caracaraí (RR). The questionnaire was applied using mobile devices (tablets and mobile phones) with Android operating system. The free Open Data Kit (ODK) toolkit (Madrid, 2015) was adopted to support the data collection process of this research. The specified collection instrument was implemented for use on the platform. The choice of this solution is justified for two reasons: 1) extensive experience of one of the members of the project team with the use of this type of data collection instrument; 2) because ODK is a solution that allows: the creation of customized questionnaires, offline data collection; and subsequent synchronization to a central server (due to the low connectivity in Amazon). Furthermore, the use of this solution focused on data integrity, reducing the risk of missing questionnaires, errors in filling in (and consistency) and difficulties in interpreting the digitization of responses. The ODK even favored that the analysis of the collected data could be started right after the workshops were held, eliminating the usual delay of digitizing the data from paper questionnaires (Daltio, Martinho, Magalhães, \& Carvalho, 2015).

* Step 3: Treatment and analysis of data, stage of the diagnosis that consisted of the preparation and analysis of the collected data, mentioned in Step 2. These data were exported from the ODK and processed to be analyzed by the Statistical Analysis System (SAS) (Universidade Estadual de Campinas, 2016). Descriptive statistics was adopted as the method of data analysis. This type of method gathers a set of values of the same nature, obtained from data collected from a sample or population, which makes it possible to obtain information about the central tendency and the dispersion of these data, without distortion or loss of information (Réjean, 2002).

The results regarding the characterization of the research participants (Part 1 of the questionnaire) and the skills that the participants have in MIL (Part 2 of the questionnaire) will be described in the Results section.

\section{Results}

\subsection{Characterization of the Research Participants}

The research included 145 individuals, predominantly young students from EFA and CFR from seven of the eight cities in the Amazon Biome chosen to be part of the IGGTS Project. It is important to note that in the state of Amazonas it was not possible to collect data from students for the following reasons: 1) difficulty in contacting riverside schools to schedule a visit; 2) researchers' difficulty in accessing riverside field schools; and 3) lack of financial resources and conditions for lodging and meals in the localities where the riverside field schools are located. 
Of the 145 students who make up the universe of research, 66.3\% are men and $33.7 \%$ are women. The majority of the population that took part in the research was composed of students (78.6\%), aged between 15 and 20 years old. $40 \%$ of respondents have a vocational course, that is, they have a specialization in some area. $29.6 \%$ of those surveyed continued their studies and advanced to high school, which corresponds to the last stage of basic Brazilian education. Only 9\% of respondents reported that they are in the first grades of elementary school. Table 1 records the detailed information about the characterization of the research subjects.

The 2019 School Census conducted by the National Institute of Educational Research Anísio Teixeira (Inep), an organ of the Ministry of Education (MEC) of the Federal Government of Brazil, is the most important survey of statistical data on education in the country (Instituto Nacional de Estudos e Pesquisas Educacionais Anísio Teixeira, 2019). Its objective is to identify the educational situation in the entire Brazilian territory. Its results serve as a basis for the implementation of a set of public policies in this area. This census diagnoses basic education in public schools, including state and municipal, urban and rural networks, as well as in private schools, surveying, among other things, the number of students enrolled in daycare, pre-school, elementary and secondary education, both in regular education and in youth and adult education.

Making a cut of the data collected in the School Census 2019 (Instituto Nacional de Estudos e Pesquisas Educacionais Anísio Teixeira, 2019) referring to the enrollment of elementary and high school students in the rural area of the state and municipal network, it appears that in the cities included in the present study the percentage of students enrolled in the rural area of state and municipal schools represents $0.012 \%$ in relation to the total number of individuals enrolled in the same teaching modalities in the rural area throughout Brazil (Table 2).

The low number of rural students enrolled in elementary and high school in 2019 in the locations that made up this research is a reflection of Brazil's historic neglect of this important social segment. In 2014, Brazil defined the National

Table 1. Characterization of the research participants.

\begin{tabular}{|c|c|c|c|c|c|c|c|c|c|c|}
\hline \multicolumn{3}{|c|}{ Genre (\%) } & \multicolumn{6}{|c|}{ Age range $(\%)$} & \multirow[b]{2}{*}{$51-56$} & \multirow[b]{2}{*}{+60} \\
\hline Woman & Man & $15-20$ & $21-25$ & $26-30$ & $31-35$ & $36-40$ & $41-45$ & $46-50$ & & \\
\hline 33.7 & 66.3 & 78.6 & 7 & 2.7 & 5.5 & 1.4 & 2.7 & - & 1.4 & 0.7 \\
\hline \multicolumn{11}{|c|}{ Occupation } \\
\hline \multicolumn{2}{|c|}{$\begin{array}{l}\text { They did not } \\
\text { answer }\end{array}$} & Students & \multicolumn{2}{|c|}{$\begin{array}{c}\text { Rural Extension } \\
\text { Technician }\end{array}$} & Teacher & Rural Owner & \multicolumn{2}{|l|}{ Rural worker } & Seated & Others \\
\hline \multicolumn{2}{|c|}{9.7} & 78.6 & \multicolumn{2}{|c|}{2.1} & 3.4 & - & 2.8 & \multicolumn{2}{|c|}{-} & 3.4 \\
\hline \multicolumn{11}{|c|}{ Education level } \\
\hline \multicolumn{3}{|c|}{ They did not answer } & \multicolumn{3}{|c|}{ Vocational Course } & \multicolumn{2}{|c|}{ Elementary School } & \multicolumn{3}{|c|}{ High school } \\
\hline \multicolumn{3}{|c|}{21.4} & \multicolumn{3}{|c|}{40.0} & \multicolumn{2}{|c|}{9.0} & \multicolumn{3}{|c|}{29.6} \\
\hline
\end{tabular}


Table 2. Student enrollments in 2019 in the rural area, in the state and municipal education networks, in the cities included in the research.

\begin{tabular}{|c|c|c|}
\hline \multirow{2}{*}{ City } & Elementary School & \multirow{2}{*}{$\begin{array}{c}\text { High school } \\
\text { Number of enrollments }\end{array}$} \\
\hline & Number of enrollments & \\
\hline Acrelândia (AC) & 723 & 150 \\
\hline Macapá (AP) & 10.339 & 1.479 \\
\hline São Luiz (MA) & 17.128 & 2.368 \\
\hline Juína (MT) & 702 & 142 \\
\hline Marabá (PA) & 8.585 & 1.018 \\
\hline Ji-Paraná (RO) & 1.879 & 56 \\
\hline Caracaraí (RR) & 1.484 & 151 \\
\hline Total & 40.840 & 5.364 \\
\hline Grand total cities & \multicolumn{2}{|c|}{46.204} \\
\hline Brazil & 3.427 .838 & 326.853 \\
\hline Grand total Brazil & \multicolumn{2}{|c|}{3.754 .691} \\
\hline$\%$ Enrollment region $\mathrm{x}$ Brazil & \multicolumn{2}{|c|}{0.012} \\
\hline
\end{tabular}

Source: Instituto Nacional de Estudos e Pesquisas Educacionais Anísio Teixeira, 2019.

Education Plan (PNE) containing twenty goals aimed at education of the population. In this PNE, national education priorities were made explicit in terms of quality, structure, financial investments, access, permanence and student success. Despite the establishment of these goals regarding education of the field, it was always observed "[...] low educational levels and also deteriorated schools, low qualified personnel, low amount of equipment and educational material, schools without electricity and drinking water, etc." (Santos, 2018). It is also noted that education of the field has never had its demands met, while simultaneously facing difficulties to guarantee the universal right to education.

In addition to the issues mentioned above, there is still the difficulty and complexity of obtaining reliable data on education of the field in the Amazon region. According to the Sustainable Amazonas Foundation (FAS) and the United Nations Children's Fund (UNICEF), the collection of data on rural Amazonia is multifaceted and imposes even greater obstacles compared to other regions due to the "[...] long distances and high logistical costs challenge the collection of information in loco in rural communities and hinder an analysis of the educational situation of the Amazonian interior. A lack of knowledge about the educational reality compromises the adoption of public policies and programs that respond to the different realities in the interior of the region" (Fundação Amazonas Sustentável, 2017). This reality reveals the difficulties faced in the full adoption of digital technologies by rural schools in the Amazon region, especially regarding compliance with the guidelines established in the Brazil's National Common Curricular Base (BNCC) (Brasil, 2017). 


\subsection{Characterization of Research Participants Regarding MIL}

This study presents a characterization of the capacity (skill/competency) that the research participants have to access, analyze, evaluate, produce, act and distribute information and media content in various formats and different digital tools. Media is understood as all electronic or digital media and artistic or printed visuals used to transmit messages (National Association for Media Literacy Education, 2020). MIL in of great relevance for the IGGTS Project since one of the main results is the availability of a geodigital technological solution aimed at territorial management. This solution requires that young people have skills/competencies in using and dominating the media, especially on the web, to perform basic tasks, identify information, evaluate, share, organize, produce content, participate in training and distance education events and interact with people to develop critical thinking, express opinions and exercise citizenship. The geodigital inclusion proposed by the IGGTS Project includes the development of a training action that promotes digital literacy by the engagement.

Digital literacy is a dynamic concept that has evolved since the intensification of the use of the web in the different dimensions of human life (cultural, civic, economic, social, etc.). It refers to a specific set of information skills applied to text and multimedia information found on the web (Meyers, Erickson, \& Small, 2013). The emergence of web 2.0 has propelled the participatory culture that refers to the active roles of producers and consumers of information that people have come to assume (Jenkins, 2008). This new culture requires even more that people have the skills to express, create, share, interact and engage with collective and collaborative actions. Digital literacy is now a broad concept that involves a spectrum of actions ranging from the ability to use and apply digital technologies to those of locating, extracting, organizing, managing, presenting and evaluating information in digital environments and broader and more complex conceptual structures that encompass a wide variety of skills, understandings, norms and practices (Meyers, Erickson, \& Small, 2013).

The skills/competencies in MIL were raised in Part 2 of the questionnaire. In this part of the questionnaire, a more general question was inserted, which referred to the identification of the digital technologies used by the respondents and a set of three more specific questions related to the skills/competencies that they believe they have for: 1) perform basic tasks on the web; 2) identify information on the web in order to develop critical thinking; and 3) expressing opinions and producing content on the web. For each of these three sets of skills/competencies, respondents were asked to report, using a four-point scale, how much they used and dominated them. It was necessary to identify these two aspects related to the set of the three skills/competencies to support the definition of a training program. This action aimed to develop the skills/competencies necessary to become able to use technologies to produce content in the most diverse digital media. Next, the results of each of the questions in Step 2 of the questionnaire will be presented and analyzed. 


\subsubsection{Identification of Digital Technologies Used by Respondents}

In this question, we tried to identify the digital technologies that respondents used most. There were eight options of digital technologies (mobile phone/smartphone; portable computer; desktop computer, tablet, multimedia project, digital camera, MP3 player and others) for them to tick, and they could register more than one option. Among the technologies most used by the research subjects are the mobile phone/smartphone, with 123 records, and the desktop and laptop computer, with 69 records (Table 3). As for the other technologies, it was observed that the frequency of use varied between 11 and 15 records.

Although in the questionnaire the technologies portable computer (laptop/notebook) and desktop computer (desktop/PC) were considered different digital technologies, in practice, when the data collection instrument was applied, it was found that the research participants consider them as a single technology, which is why they were counted together.

As noted in Table 3, the mobile phone/smartphone is the most used digital technology by the research participants. In fact, the mobile phone has been identified as the technology that has most contributed to the construction of the youth's identity (Castells, Fernández-Ardèvol, Lincham, \& Sey, 2009). Young people are quick to appropriate digital technologies, and make intensive use of them, becoming more and more autonomous, in addition to being the social group most interconnected by wireless communications (Nagumo, 2014). It is known that society today is experiencing an intense process of digital transformation that invades all dimensions of human life, in particular, the educational dimension focused on pedagogical practices. Considering this reality, digital technologies, when used with an educational intent, have the potential to promote the expansion of people's ability to perceive the world and change their own reality.

In this sense, the use of mobile phones/smartphones and portable and desktop computers in the Amazon is of great importance for the region. They can serve the purpose of favoring the participation of young people in the community in which they live, especially if such technologies are used by them from the perspective of the MIL conceptual approach (Núcleo de Informação e Coordenação do Ponto BR, 2019). However, to serve this purpose, it is not enough that young

Table 3. Frequency of digital technologies most used by research participants.

\begin{tabular}{cc}
\hline Technologies digital & Frequency \\
\hline Mobile phone/smartphone & 123 \\
Laptop/Desktop computer & 69 \\
Multimedia projector (Datashow) & 15 \\
Digital camera & 14 \\
Tablet & 11 \\
MP3 player & 5 \\
Others & 4
\end{tabular}


people have access to technologies in the school environment. It is also necessary that they develop skills/competencies to understand and use the information acquired through these technologies. Developing MIL means enabling young people to make sense of reading and the information they acquire in digital texts. It therefore means an act "[...] of cognition of what is visualized on the screen, of what is heard in sound files, of what is perceived in simulations or animations, of what is built with others in the search for useful texts for daily activities" (Gomez, 2002). MIL is seen as a fundamental skill/competency for the health and well-being of students and for their future participation in civic and economic life (Media Literacy Now, 2020).

The Brazil's National Common Curricular Base (BNCC), a document that in Brazil defines the essential learning to be worked on in schools, public and private, in Early Childhood Education, Elementary School and High School; suggests that MIL skills/competencies are developed in such a way that students understand and use digital technologies while also being able to act, actively and critically, in media spaces (Brasil, 2017). The BNCC admits that the strategy of developing MIL skills/competencies in students is fundamental for a formation that is " $[. .$.$] critical, meaningful, reflective and ethical in the different social prac-$ tices (including school ones)" (Brasil, 2017). The document also records the need for schools to have pedagogical planning for the use of these resources together with the definition of clear objectives that favor the teaching and learning processes aimed at developing the protagonism and authorship of the students.

In view of these guidelines and considering the obstacles inherent to the reality observed in the Amazon Biome, the mobile phone together with the computer (portable or desktop) are positioned as digital technologies combined with the strategies that corroborate to enhance the development of skills/competencies aimed at MIL.

\subsubsection{Skills/Competencies to Perform Basic Tasks on the Web}

Given that one of the interests of the IGGTS Project is to develop a technological solution for territorial management and the generation of sustainability indexes, nine skills/competencies concerning the MIL related to the use/mastery of digital technologies were raised, which are considered important for students to perform tasks basic on the web. They are:

1) Copy and paste text from the web. Copy and paste text from the web to Microsoft Word, LibreOffice Writer or another word processor.

2) Insert pictures in a Microsoft Word, LibreOffice Writer or other processors.

3) Create and format a table in Microsoft Word, LibreOffice Writer or another word processor.

4) Make presentations using Microsoft PowerPoint, LibreOffice Impress or other software.

5) Use search strategies to get information to the web more easily.

6) Know the different types of file extensions: rar, txt, pdf, doc, docx, odt, zip.

7) Know how to fill in data in a spreadsheet of Microsoft Excel, LibreOffice 
Calc or other.

8) Know how to do basic calculations with data from a spreadsheet of Microsoft Excel, LibreOffice Calc or other.

9) Know how to download software and applications (apps) for the computer and mobile phone/tablet from the web.

For each of the nine skills/competencies mentioned above, respondents had to point out how much they used and dominated them, considering a scale of four points distributed as follows: 1) does not use/does not dominate; 2) uses little/dominate little; 3) uses when needed/dominated; and 4) uses a lot/dominate a lot.

Bearing in mind that the results of the three sets of specific questions, contained in Part 2 of the questionnaire, would serve as a basis for the elaboration of a training program for young people from EFAs and CFRs, it was sought to know which MIL skills/competencies the youngsters had less control over and which ones they used the most. This information is relevant because it will subsidize the training program providing guidance on the contents that should be prioritized to supply the learning of those skills/competencies that young people are less familiar with and use more.

Table 4 shows the skills/competencies that young people from EFAs and CFRs have less control over. To identify the percentage of frequency of domain of skills/competencies, the number of responses given in scales 1 and 2 was added (does not dominate and dominate little, respectively).

Table 4. Domain of skills/competencies to perform tasks on the web.

\begin{tabular}{|c|c|c|}
\hline $\begin{array}{l}\text { Skills/competencies } \\
\text { (in decreasing order of domain) }\end{array}$ & $\%$ non-responders & $\%$ of frequency \\
\hline $\begin{array}{l}\text { 8-Know how to do basic calculations with data from a } \\
\text { spreadsheet of Microsoft Excel, LibreOffice Calc or other. }\end{array}$ & 0.7 & 62.8 \\
\hline $\begin{array}{l}\text { 6-Know the different types of file extensions: rar, txt, pdf, } \\
\text { doc, docx, odt, zip. }\end{array}$ & 1.4 & 60.7 \\
\hline $\begin{array}{l}\text { 7-Know how to fill in data in a spreadsheet of Microsoft } \\
\text { Excel, LibreOffice Calc or other. }\end{array}$ & 2.7 & 60.0 \\
\hline $\begin{array}{l}\text { 3-Create and format a table in Microsoft Word, } \\
\text { LibreOffice Writer or another word processor. }\end{array}$ & 3.5 & 54.5 \\
\hline $\begin{array}{l}2 \text {-Insert pictures in a Microsoft Word, LibreOffice Writer } \\
\text { or other processor. }\end{array}$ & 4.1 & 47.6 \\
\hline $\begin{array}{l}1 \text {-Copy and paste text from the web. Copy and paste text } \\
\text { from the web to Microsoft Word, LibreOffice Writer or } \\
\text { another word processor. }\end{array}$ & 1.4 & 42.0 \\
\hline $\begin{array}{l}\text { 4-Make presentations using Microsoft PowerPoint, } \\
\text { LibreOffice Impress or other software. }\end{array}$ & 2.1 & 40.0 \\
\hline $\begin{array}{l}9-\text { Know how to download software and applications } \\
\text { (apps) for the computer and mobile phone/tablet from the } \\
\text { web. }\end{array}$ & 0.7 & 28.3 \\
\hline $\begin{array}{l}5 \text {-Use search strategies to get information to the web more } \\
\text { easily. }\end{array}$ & 2.1 & 27.6 \\
\hline
\end{tabular}


Table 5 presents the skills/competencies that young people from EFAs and CFRs use most. To identify the percentage of frequency of use of skills/ competencies, the number of responses given in scales 3 and 4 was added (uses when needed and uses a lot, respectively).

Analyzing Table 4 and Table 5, it can be observed that the skill/competency of number $8-$ Know how to make basic calculations with data from a Microsoft Excel, LibreOffice Calc or other spreadsheets-is the least domain by young people (62.8\%) and also the one they use the least (44.1\%). The skills/competencies of numbers 1, 2, 3, 4, 6 and 7 are the ones that young people least dominate and use the most, so they are the ones that should be given priority in the training course on MIL to be offered by the IGGTS Project. The skills/competencies that young people dominate the most and also use the most are numbers 9 and 5.

\subsubsection{Skills/Competencies to Identify Information on the Web}

This set of skills/competencies is related to those that favor the research subjects to identify information on the web. An important aspect that involves the concept of MIL is related to information. In the society called knowledge society, connected by digital technologies, information is the basis that allows individuals to observe, experience and transform reality. In this sense, it is extremely important that young people from EFAs and CFRs have the capacity to know when it is "[...] necessary to obtain information; what information is needed; where and how to obtain this information; how to evaluate it critically, and once

Table 5. Use of skills/competencies to perform tasks on the web.

\begin{tabular}{|c|c|c|}
\hline $\begin{array}{c}\text { Skills/competencies } \\
\text { (in decreasing order of use) }\end{array}$ & $\%$ non-responders & $\%$ of frequency \\
\hline $\begin{array}{l}\text { 9-Know how to download software and applications } \\
\text { (apps) for the computer and mobile phone/tablet from the } \\
\text { web. }\end{array}$ & 2.8 & 72.4 \\
\hline $\begin{array}{l}5 \text {-Use search strategies to get information to the web more } \\
\text { easily. }\end{array}$ & 3.5 & 65.5 \\
\hline $\begin{array}{l}\text { 4-Make presentations using Microsoft PowerPoint, } \\
\text { LibreOffice Impress or other software. }\end{array}$ & 4.1 & 64.2 \\
\hline $\begin{array}{l}1-\text { Copy and paste text from the web. Copy and paste text } \\
\text { from the web to Microsoft Word, LibreOffice Writer or } \\
\text { another word processor. }\end{array}$ & 2.7 & 58.7 \\
\hline $\begin{array}{l}\text { 2-Insert pictures in a Microsoft Word, LibreOffice Writer } \\
\text { or other processors. }\end{array}$ & 5.5 & 51.1 \\
\hline $\begin{array}{l}\text { 6-Know the different types of file extensions: rar, txt, pdf, } \\
\text { doc, docx, odt, zip. }\end{array}$ & 1.4 & 45.5 \\
\hline $\begin{array}{l}\text { 3-Create and format a table in Microsoft Word, } \\
\text { LibreOffice Writer or another word processor. }\end{array}$ & 4.8 & 44.8 \\
\hline $\begin{array}{l}\text { 7-Know how to fill in data in a spreadsheet of Microsoft } \\
\text { Excel, LibreOffice Calc or other. }\end{array}$ & 2.8 & 44.8 \\
\hline $\begin{array}{l}\text { 8-Know how to do basic calculations with data from a } \\
\text { spreadsheet of Microsoft Excel, LibreOffice Calc or other. }\end{array}$ & 3.5 & 44.1 \\
\hline
\end{tabular}


found how to organize it; and how to use that information ethically. [...] information and media literacy is an emerging field of human rights in an increasingly digital, interdependent and global world, which promotes greater social inclusion " $[. .$.$] strengthens individuals and provides them with knowledge of the$ functions of information systems and the media and the conditions under which these functions are performed" (IFLA, 2011).

Five informational skills/competencies were raised, as follows:

1) Use the web to find and access information related to professional/student interests.

2) Use the web to appreciate information and build critical thinking on topics of professional/student interests.

3) Use the web to share information of professional/student interests.

4) Use the web to organize information of professional/student interests.

5) Use the web to interact/communicate with people by exchanging images, texts and/or information/knowledge/experiences etc. of professional/student interests.

The analysis of the five informational skills/competencies followed the same rationale used to analyze the nine skills/competencies related to the use of the web. In this way, the interest prevailed in identifying which skills/competencies of information literacy the young people dominated less and which ones they used more. Such skills/competencies are will be priorities in the training program that will be given to them in another phase of the Project IGGTS.

Table 6 shows the skills/competencies that young people dominate less. It is worth mentioning that the percentage of frequency of domain of these skills/competencies took into account the sum of the answers given in scales 1 and 2 (does not dominate and dominate little, respectively) in the questionnaire.

Table 7 presents the informational skills/competencies that young people from EFAs and CFRs use most. The criterion for defining the percentage of frequency of use followed the same logic already informed, that is, the number of

Table 6. Domain of skills/competencies to deal with information on the web.

\begin{tabular}{|c|c|c|}
\hline $\begin{array}{l}\text { Skills/competencies } \\
\text { (in decreasing order of domain) }\end{array}$ & $\%$ non-responders & $\%$ of frequency \\
\hline $\begin{array}{l}2 \text {-Use the web to appreciate information and build critical } \\
\text { thinking on topics of professional/student interests. }\end{array}$ & 1.4 & 37.9 \\
\hline $\begin{array}{l}\text { 4-Use the web to organize information of } \\
\text { professional/student interests. }\end{array}$ & 4.8 & 35.9 \\
\hline $\begin{array}{l}\text { 3-Use the web to share information of profession- } \\
\text { al/student interests. }\end{array}$ & 2.8 & 33.8 \\
\hline $\begin{array}{l}1 \text {-Use the web to find and access information related to } \\
\text { professional/student interests. }\end{array}$ & 2.1 & 30.3 \\
\hline $\begin{array}{l}\text { 5-Use the web to interact/communicate with people by } \\
\text { exchanging images, texts and/or information/knowledge/ } \\
\text { experiences etc. of professional/student interests. }\end{array}$ & 2.1 & 20.0 \\
\hline
\end{tabular}


Table 7. Use of skills/competencies to handle information on the web.

\begin{tabular}{lcc}
\hline \multicolumn{1}{c}{$\begin{array}{l}\text { Skills/competencies } \\
\text { (in decreasing order of use) }\end{array}$} & \% non-responders & \% of frequency \\
\hline $\begin{array}{l}\text { 5-Use the web to interact/communicate with people by } \\
\text { exchanging images, texts and/or information/knowledge/ } \\
\text { experiences etc. of professional/student interests. }\end{array}$ & 2.1 & 77.2 \\
$\begin{array}{l}\text { 1-Use the web to find and access information related to } \\
\text { professional/student interests. }\end{array}$ & 3.5 & 66.1 \\
$\begin{array}{l}\text { 3-Use the web to share information of } \\
\text { professional/student interests. }\end{array}$ & 4.1 & 62.1 \\
$\begin{array}{l}\text { 2-Use the web to appreciate information and build critical } \\
\text { thinking on topics of professional/student interests. }\end{array}$ & 3.5 & 59.3 \\
$\begin{array}{l}\text { 4-Use the web to organize information of } \\
\text { professional/student interests. }\end{array}$ & 5.5 & 56.5 \\
\hline
\end{tabular}

responses given in scales 3 and 4 was added (uses when needed and uses a lot, respectively).

Table 6 shows that the domain of the respondents' five information skills/competencies is less than $40 \%$; while their use ranges from $56 \%$ to $77 \%$, as shown in Table 8 . This indicates that, although they are widely used by young people, these five skills/competencies are not dominated by them. That is, they do not know how to use them in order to get the best out of their profession$\mathrm{al} /$ student activities. This finding indicates that more attention is needed when structuring the training program that will be built for these young people in the IGGTS Project.

Although all five skills/competencies need to be worked on in the training program as they are not dominated, skill/competency number 5 (Using the web to interact/communicate with people by exchanging images, texts and/or information/knowledge/experiences etc. of professional/student interests) is the one that respondents say they have the most control over (20.0\%, Table 6), and also the one they say they use the most (77.2\%, Table 7).

Among the informational skills/competencies that respondents say they do not dominate (Table 6) are those of numbers 2 (Use the web to appreciate information and build a critical sense on topics of professional/student interests-37.9\%); number 4 (Use the web to organize information of professional/student interests-35.9\%); and number 3 (Use the web to share information of professional/student interests-33.8\%). Among these three informational skills/competencies the ones respondents use more (Table 7) are those of numbers 3 (Use the web to share information of professional/student interests-62.1\%); and number 2 (Use the web to enjoy information and build critical thinking on topics of profession$\mathrm{al} /$ student interests-59.3\%). The informational skill/competency of number 1 (Using the web to find and access information related to professional/student interests) is dominated by $30.4 \%$ of respondents (Table 7), although it is used by $66.1 \%$ of them (Table 7). 


\subsubsection{Skills/Competencies to Express Opinions and Produce Content on the Web}

In this set of skills/competencies, there was an attempt to identify the capacity that young people who participated in this research have to produce thoughts, ideas, opinions, criticisms, suggestions, feelings, behaviors, etc. on the web, and also to create content/media products. This set of skills/competencies is extremely important for these young people to be able to take a position on their realities. It is not enough just to know how to use digital technologies and to interpret the information abstracted from them. Today, it is essential that these young people also know, from them, to emanate their own opinions about what impacts them.

From this perspective, MIL is understood as a multiplier and leveraging element of democratization worldwide. In other words, the development of skills/ competencies that aim to enable young people to express and produce content on the web is essential for the improvement of social, economic and cultural conditions, especially in the Amazon Biome.

There are seven skills/competencies that have been identified as important to enable young people to express their opinions and produce content on the web:

1) Critically analyze the content accessed on the web through the computer and/or mobile phone/tablet and/or social media.

2) Critically evaluate the content accessed on the web through the computer and/or mobile phone/tablet and/or social media.

3) Use the computer and/or mobile phone/tablet and/or social media to express opinions on the web.

4) Use the computer and/or mobile phone/tablet and/or social media to produce content of professional/student interests on the web.

5) Use the computer and/or mobile phone/tablet and/or social media to listen to the radio and/or watch movies on the web.

6) Use the computer and/or mobile phone/tablet and/or social media to participate in professional training events such as seminars, congresses, debates etc. on the web.

7) Use the computer and/or mobile phone/tablet and/or social media to participate in distance education events in virtual learning environments on the web and/or on the cell phone/tablet.

For this set of skills/competencies, the same analysis criterion was adopted for the two other sets of skills/competencies presented above. Thus, those skills/competencies for expressing opinions and producing content on the web that the youngsters were less familiar with and those they used the most were analyzed.

Table 8 shows the skills/competencies that young people are less familiar with when it comes to expressing opinions and producing content on the web. It is worth mentioning that the percentage of frequency of domain of these skills/competencies took into account the sum of the answers given in scales 1 and 2 (does not dominate and dominate little, respectively) in the questionnaire. 
Table 8. Domain of skills/competencies to express opinions and produce content on the web.

\begin{tabular}{|c|c|c|}
\hline $\begin{array}{c}\text { Skills/competencies } \\
\text { (in decreasing order of domain) }\end{array}$ & $\%$ non-responders & $\%$ of frequency \\
\hline $\begin{array}{l}\text { 7-Use the computer and/or mobile phone/tablet and/or } \\
\text { social media to participate in distance education events in } \\
\text { virtual learning environments on the web and/or on the cell } \\
\text { phone/tablet. }\end{array}$ & 2.1 & 51.7 \\
\hline $\begin{array}{l}\text { 6-Use the computer and/or mobile phone/tablet and/or } \\
\text { social media to participate in professional training events } \\
\text { such as seminars, congresses, debates etc. on the web. }\end{array}$ & 2.8 & 48.9 \\
\hline $\begin{array}{l}\text { 2-Critically evaluate the content accessed on the web } \\
\text { through the computer and/or mobile phone/tablet and/or } \\
\text { social media. }\end{array}$ & 1.4 & 37.9 \\
\hline $\begin{array}{l}\text { 1-Critically analyze the content accessed on the web } \\
\text { through the computer and/or mobile phone/tablet and/or } \\
\text { social media. }\end{array}$ & 1.4 & 35.8 \\
\hline $\begin{array}{l}\text { 3-Use the computer and/or mobile phone/tablet and/or } \\
\text { social media to express opinions on the web. }\end{array}$ & 1.4 & 33.8 \\
\hline $\begin{array}{l}\text { 4-Use the computer and/or mobile phone/tablet and/or } \\
\text { social media to produce content of professional/student } \\
\text { interests on the web. }\end{array}$ & 2.1 & 33.1 \\
\hline $\begin{array}{l}\text { 5-Use the computer and/or mobile phone/tablet and/or } \\
\text { social media to listen to the radio and/or watch movies on } \\
\text { the web. }\end{array}$ & 2.7 & 4.5 \\
\hline
\end{tabular}

Regarding the use of skills/competencies related to the expression of opinions/production of content on the web, the answers given by the young people on scales 3 and 4 (uses when needed and uses a lot, respectively) of the questionnaire were used. Table 9 records the synthesis of skills/competencies, starting with the most used to the least used.

It can be affirmed from the analysis of Table 8 that among the skills/competencies registered as important to express opinions and produce content, those that the youngsters least dominate are those of number 7 (Use the computer and/or mobile phone/tablet and/or social media to participate in distance education events in virtual learning environments on the web and/or on the cell phone/tablet-51.7\%) and number 6 (Use the computer and/or mobile phone/ tablet and/or social media to participate in professional training events such as seminars, congresses, debates etc. on the web-48.9\%). In parallel, it is also observed in Table 9 that these are the same skills/competencies that young people say they use less (45.6\% for skill/competency 6 ; and 37.8\% for skill/competency 7). This finding may be related to a series of factors that go beyond the lack of capacity of young people, among which the following stand out: the difficulty of accessing the internet, absence of computers in schools and at home, absence of time to dedicate to activities of training and distance education etc. Although they are two important skills/competencies, they are not widely used, but they 
Table 9. Use of skills/competencies to express opinions and produce content on the web.

\begin{tabular}{|c|c|c|}
\hline $\begin{array}{c}\text { Skills/competencies } \\
\text { (in decreasing order of use) }\end{array}$ & $\%$ non-responders & $\%$ of frequency \\
\hline $\begin{array}{l}\text { 5-Use the computer and/or mobile phone/tablet and/or } \\
\text { social media to listen to the radio and/or watch movies on } \\
\text { the web. }\end{array}$ & 2.7 & 75.9 \\
\hline $\begin{array}{l}\text { 1-Critically analyze the content accessed on the web } \\
\text { through the computer and/or mobile phone/tablet and/or } \\
\text { social media. }\end{array}$ & 1.4 & 64.8 \\
\hline $\begin{array}{l}\text { 4-Use the computer and/or mobile phone/tablet and/or } \\
\text { social media to produce content of professional/student } \\
\text { interests on the web. }\end{array}$ & 2.1 & 64.1 \\
\hline $\begin{array}{l}\text { 2-Critically evaluate the content accessed on the web } \\
\text { through the computer and/or mobile phone/tablet and/or } \\
\text { social media. }\end{array}$ & 1.4 & 61.4 \\
\hline $\begin{array}{l}\text { 3-Use the computer and/or mobile phone/tablet and/or } \\
\text { social media to express opinions on the web. }\end{array}$ & 1.4 & 59.3 \\
\hline $\begin{array}{l}\text { 6-Use the computer and/or mobile phone/tablet and/or } \\
\text { social media to participate in professional training events } \\
\text { such as seminars, congresses, debates etc. on the web. }\end{array}$ & 2.8 & 45.6 \\
\hline $\begin{array}{l}\text { 7-Use the computer and/or mobile phone/tablet and/or } \\
\text { social media to participate in distance education events in } \\
\text { virtual learning environments on the web and/or on the cell } \\
\text { phone/tablet. }\end{array}$ & 2.1 & 37.8 \\
\hline
\end{tabular}

should be the subject of attention in the training program to be offered to young people.

The skills/competencies to express opinions and produce content that deserve to be highlighted in the training program that will be developed for young people are those of number 2 (Critically evaluate the content accessed on the web through the computer and/or mobile phone/tablet and/or social media-Domain: $37.9 \%$ and Use: $61.4 \%$ ); number 1 (Critically analyze the content accessed on the web through the computer and/or mobile phone/tablet and/or social media-Domain $35.8 \%$ and Use: $64.8 \%$ ); number 3 (Use the computer and/or mobile phone/tablet and/or social media to express opinions on the web-Domain: $33.8 \%$ and Use: 59,3\%); and number 4 (Use the computer and/or mobile phone/tablet and/or social media to produce content of profession$\mathrm{al} /$ student interests on the web-Domain: $33.1 \%$ and Use: $64.1 \%)$. These skills/competencies are that students dominate little (Table 9) and, at the same time, use a lot (Table 9). The skill/competency of number 5 (Use the computer and/or mobile phone/tablet and/or social media to listen to the radio and/or watch movies on the web) is the one of the youngers most dominate (14.5\%) and also the most use (51.7\%).

Table 10 presents a summary of which skills/competencies, among the set of three skills/competencies (performing basic tasks, identifying information and expressing opinions/producing content on the web), presented above, should be prioritized in the training program for young people. This synthesis will guide 
Table 10. Set of skills/competencies to be worked on in the training program by domain/use priority.

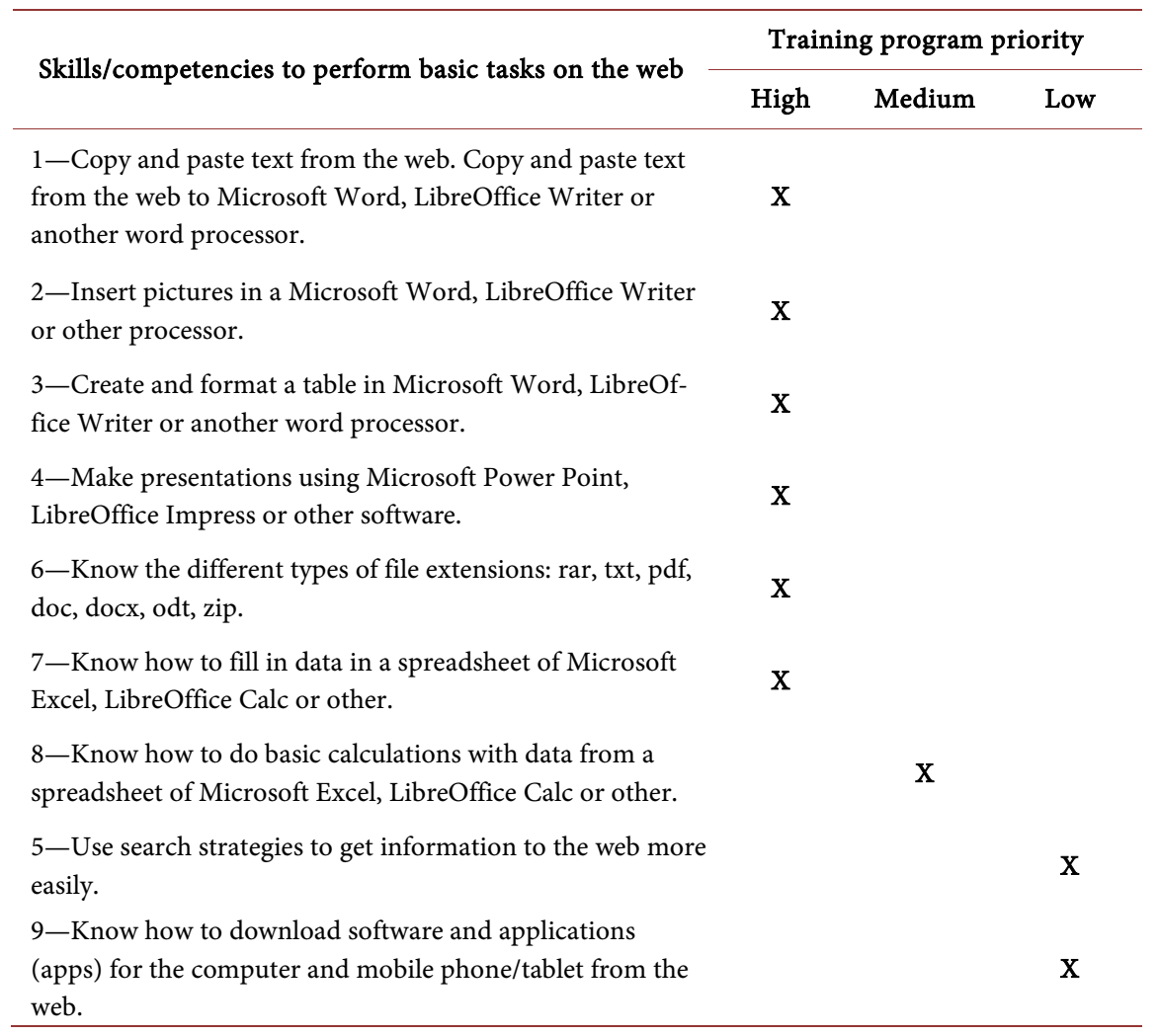

\begin{tabular}{|c|c|c|c|}
\hline \multirow{2}{*}{ Skills/competencies to identify information on the web } & \multicolumn{3}{|c|}{ Training program priority } \\
\hline & High & Medium & Low \\
\hline $\begin{array}{l}\text { 2-Use the web to appreciate information and build critical } \\
\text { thinking on topics of professional/student interests. }\end{array}$ & $\mathrm{X}$ & & \\
\hline $\begin{array}{l}\text { 4-Use the web to organize information of } \\
\text { professional/student interests. }\end{array}$ & $\mathrm{x}$ & & \\
\hline $\begin{array}{l}\text { 3-Use the web to share information of profession- } \\
\text { al/student interests. }\end{array}$ & $\mathrm{X}$ & & \\
\hline $\begin{array}{l}1 \text { - Use the web to find and access information related to } \\
\text { professional/student interests. }\end{array}$ & $\mathrm{x}$ & & \\
\hline $\begin{array}{l}\text { 5-Use the web to interact/communicate with people by } \\
\text { exchanging images, texts and/or information/knowledge/ } \\
\text { experiences etc. of professional/student interests. }\end{array}$ & & $\mathrm{x}$ & \\
\hline
\end{tabular}




\section{Continued}

3-Use the computer and/or mobile phone/tablet and/or

social media to express opinions on the web.

4-Use the computer and/or mobile phone/tablet and/or social media to produce content of professional/student interests on the web.

7-Use the computer and/or mobile phone/tablet and/or social media to participate in distance education events in virtual learning environments on the web and/or on the cell phone/tablet.

6-Use the computer and/or mobile phone/tablet and/or social media to participate in professional training events such as seminars, congresses, debates etc. on the web.

5-Use the computer and/or mobile phone/tablet and/or social media to listen to the radio and/or watch movies on the web.
$\mathrm{X}$

$\mathrm{X}$

$\mathbf{X}$

the IGGTS Project team when preparing the training program that will be taught in the next phase of the project with regard to actions aimed at using the technology that will support the system to be used to generate the sustainability index. The central idea of this training is to offer young people the content necessary to develop/strengthen the skills/competencies that will be needed to use the sustainability index generation system with the community to which they belong to support family farming actions in the Amazon Biome. It is also the objective of the training program to contribute so that these young people increase the chances of developing the minimum skills/competencies necessary to be considered literate in the digital context so that they can, from this inclusion, identify information of their interests and analyze, criticize and produce content that express their awareness of their own realities.

\section{Conclusion}

The research was conducted within the scope of the IGGTS Project with students from Agricultural Family Schools (EFA) and Rural Family House (CFR), children of small family farmers, located in the Amazon Biome. The study aimed to identify and analyze the media, informational and digital skills and competencies present in the daily lives of these students, having as reference the precepts of media literacy (MIL). The research was oriented towards the construction of the theoretical and practical foundations focused on actions in the non-formal education modality, aiming to meet the interests and needs of the students involved in the study. The results obtained by the diagnosis made will be essential to introduce the inclusive education approach from the perspective of MIL, emphasizing it as the driving force behind the exercise of citizenship, understood as a gateway to universal human rights, guaranteed by the United Nations (UN).

This research contributes to creating opportunities that will be created for local agents, development agents and family farmers to establish new levels of so- 
cial organization, making it possible to reconcile productivity, conservation of natural resources and social equity through the provision of a training program for young people from family farming that aims to develop skills/competencies to use the sustainability index generation system with the community to which they belong to support family farming actions in the Amazon Biome.

It is also the objective of the training program to contribute so that these young people increase the chances of developing the minimum skills/competencies necessary to be considered literate in the digital context so that they can, from this inclusion, identify information of their interests and analyze, criticize and produce content that expresses their awareness of their own realities.

It should also be noted that the future actions to be carried out by Embrapa, within the scope of the Integrated Amazon Project, component of the Amazon Fund Program for non-formal training of young students from rural schools in the Amazon Biome, will directly serve the "Objective 4: Ensure inclusive and equitable quality education and promote lifelong learning opportunities for all", extracted from the 17 Sustainable Development Goals (SDGs) established by the UN in 2015 to be implemented by all countries in the world by 2030 (United Nations, 2015).

Finally, it is worth noting that this research has limitations because it is a qualitative study, whose results cannot be generalized. Furthermore, the central theme of the research is multifaceted in nature, which means that its results cannot be seen in isolation. Although they can provide subsidies for the exploration of new hypotheses in future research, in the search for knowledge that broadens the question of how to develop MIL in a region as complex as the Amazon Biome.

\section{Acknowledgements}

This research was financed by the Amazon Fund, and carried out with the support of the Brazilian Development Bank of Brazil (BNDES) and the Brazilian Agricultural Research Corporation (Embrapa)

\section{Conflicts of Interest}

The authors declare no conflicts of interest regarding the publication of this paper.

\section{References}

Borges, G. (2014). Qualidade na TV pública portuguesa: Análise dos programas do canal 2. Juiz de Fora: Editora da UFJF.

Brasil. Ministério da Educação (2017). Base Nacional Comum Curricular: Educação é a base (472 p). Brasília, DF.

http://portal.mec.gov.br/index.php?option=com_docman\&view=download\&alias=796 11-anexo-texto-bncc-aprovado-em-15-12-17-pdf\&category_slug=dezembro-2017-pdf \&Itemid=30192

Campos, R. S. S. (2016). A educação do campo na Amazônia: Estudo sobre a com- 
preensão de movimentos sindicais com atuação nos espaços das florestas e das águas. In Congresso Nacional de Educação-Conedu, 3. Natal. Campina Grande. https://www.editorarealize.com.br/index.php/artigo/visualizar/19772

Castells, M., Fernández-Ardèvol, M., Lincham, Q., \& Sey, A. (2009). Mobile Communication and Society: A Global Perspective (352 p). Cambridge: MIT Press.

Côrbo, D. A. S., \& Gonçalves, M. (2015). Redes sociais digitais na esfera pública política: Exercícios de cidadania. Mídia e Cotidiano, 6, 152-168. https://doi.org/10.22409/ppgmc.v6i6.9743

Cordeiro, G. N. K., Reis, N. S., \& Hage, S. M. (2011). Pedagogia da Alternância e seus desafios para assegurar a formação humana dos sujeitos e a sustentabilidade do campo. Em Aberto, 24, 115-125.

Daltio, J., Martinho, P. R. R, Magalhães, L. A., \& Carvalho, C. A. (2015). Utilização de dispositivos móveis para coleta de dados em campo: Experiência Machadinho d'Oeste. In Congresso Brasileiro de Agroinformática-SBIAgro. Ponta Grossa: UFPG. http://ainfo.cnptia.embrapa.br/digital/bitstream/item/137257/1/17-jaudete-daltio-193.p df

Esteves, G. C., Freiria, F. A., Alves, E. C., \& Garcia, S. R. O. (2017). As Casas Familiares Rurais e a Pedagogia da Alternância: Um breve resgate histórico. In Congresso Nacional de Educação-Educere, 13.; Seminário Internacional de Representações Sociais, Subjetividade e Educação-Sirsse, 4.; Seminário Internacional sobre Profissionalização Docente (SIPD/Cátedra UNESCO), 6 (pp. 12435-12450). Curitiba: PUCP Press.

Ferreira Sobrinho, J. (2013). O MST e o manifesto/movimento em defesa da educação do campo no Brasil.

http://www.histedbr.fe.unicamp.br/acer_histedbr/jornada/jornada11/artigos/8/artigo_s imposio_8_58_prof_jfsobrinho@hotmail.com.pdf

Fundação Amazonas Sustentável (2017). Recortes e cenários educacionais em localidades rurais ribeirinhas do Amazonas (84 p). Manaus: FAS; UNICEF. https://fas-amazonas.org/wp-content/uploads/2020/03/Recortes-e-Cen\%C3\%A1rios-E ducacionais-em-Localidades-Ribeirinhas-do-Amazonas.pdf

Garces, S. B. B. (2010). Classificação e tipos de pesquisa (12 pp). Cruz Alta: Universidade de Cruz Alta.

Gomez, M. V. (2002). Alfabetização na esfera digital: Uma proposta freireana. Revista Educação em Foco, Juiz de Fora, 7, 99-115. http://www.ufjf.br/revistaedufoco/files/2010/02/06.pdf

Grizzle, A., \& Calvo, M. C.T. (Eds.) (2016). Alfabetização midiática e informacional: Diretrizes para a formulação de políticas e estratégias (208 p). Brasília, DF: UNESCO. http://unesdoc.unesco.org/images/0024/002464/246421POR.pdf

Guida, V., Borges, G., \& Sigiliano, D. (2017). As dimensões da competência midiática e a diversidade: Análise de comentários do canal Põe na Roda. In Congresso Internacional sobre Competências Midiáticas, 2 (pp. 699-708). Juiz de Fora: Universidade Federal de Juiz de Fora.

Hage, S. A. M., \& Cardoso, M. B. C. (2013). Educação do campo na Amazônia: Interfaces com a educação quilombola. Revista Retratos da Escola, 7, 425-443.

Hage, S. A. M., \& Cruz, C. R. (2015). Movimento de educação do campo na Amazônia paraense: Ações e reflexões que articulam protagonismo, precarização e regulação. In Reunião Nacional da Anped, 37. Florianópolis. Florianópolis: ANPED.

IFLA (2011). Recomendações da IFLA sobre a literacia informacional e mediática versão final. Hague, Netherlands.

https://www.ifla.org/files/assets/information-literacy/publications/media-info-lit-reco 
mmend-pt.pdf

Instituto Nacional de Estudos e Pesquisas Educacionais Anísio Teixeira (2019). Censo escolar. Brasília, DF. http://portal.inep.gov.br/censo-escolar/

Jenkins, H. (2008). Cultura da convergência. São Paulo: Aleph.

Madrid, C. (2015). Manual para a aplicação Open Data Kit. Madrid: Ongawa. https://docplayer.com.br/878304-Manual-para-a-aplicacao-open-data-kit.html

Media Literacy Now (2020). What Is Media Literacy? Watertown, MA. https://medialiteracynow.org/what-is-media-literacy/

Mello, T. R., Souza, M. V. B., \& Torres, T. Z. (2017). Redes sociais como recurso pedagógico para a formação da cidadania. In Congresso Internacional de Competências Midiáticas, 2 (pp. 663-671). Juiz de Fora: Universidade Federal de Juiz de Fora.

Meyers, E. M., Erickson, I., \& Small, R. V. (2013). Digital Literacy and Informal Learning Environments: An Introduction. Learning, Media and Technology, 38, 355-367. https://doi.org/10.1080/17439884.2013.783597

Nagumo, E. (2014). O uso do aparelho celular dos estudantes na escola. Master Dissertation, Brasília, DF: Universidade de Brasília. https://repositorio.unb.br/bitstream/10482/16856/1/2014_EstevonNagumo.pdf

National Association for Media Literacy Education (2020). Media Literacy Defined. New York, NY. https://namle.net/publications/media-literacy-definitions/

Núcleo de Informação e Coordenação do Ponto BR (Ed.) (2019). Survey on the Use of Information and Communication Technologies in Brazilian Schools: ICT in Education 2018. São Paulo: Comitê Gestor da Internet no Brasil.

https://www.cetic.br/media/docs/publicacoes/216410120191105/tic_edu_2018_livro_el etronico.pdf

Organización para la Cooperación y Desarollo Econômico (2003). Los desafios de las tecnologias de la información y las comunicaciones en la educación (189p). París: OCDE Publishing.

https://read.oecd-ilibrary.org/education/los-desafios-de-las-tecnologias-de-la-informac ion-y-las-comunicaciones-en-la-educacion_9789264103429-es\#page1

Pereira, R. C. (2017). Trajetória e realidade da educação do campo no Pará. Revista Educação, 24, 113-127.

Prazeres, M. S. C. (2013). Educação do campo e da alternância no Brasil e na Amazônia: Bases históricas. Revista HISTEDBR, 13, 357-371.

https://doi.org/10.20396/rho.v13i52.8640247

Prazeres, M. S. C., \& Carmo, E. S. (2011). Educação do campo e políticas públicas na Amazônia: Desafios e possibilidades. In Simpósio Brasileiro de Política e Administração da Educação, 25.; Congresso Ibero-Americano de Política e Administração da Educação, 2. São Paulo: Anpae.

http://www.anpae.org.br/simposio2011/cdrom2011/PDFs/trabalhosCompletos/posters/ 0104.pdf

Prazeres, M. S. C., \& Carmo, E. S. (2012). Retratos e desafios da educação do/no campo no Brasil e na Amazônia. Olhar de Professor, 15, 383-395. https://doi.org/10.5212/OlharProfr.v.15i2.0012

Réjean, H. (2002). Métodos quantitativos para as ciências humanas. Lisboa: Instituto Piaget.

Santos, M. (2018). Educação do Campo no Plano Nacional de Educação: Tensões entre a garantia e a negação do direito à educação. Ensaio: Aval. Pol. Públ. Educ., Rio de Janeiro, 26, 185-212. 
http://www.scielo.br/pdf/ensaio/v26n98/1809-4465-ensaio-26-98-0185.pdf https://doi.org/10.1590/s0104-40362018002600965

Silva, G. P., Gomes, M. S., \& Wanzeler, J. P. (2007). Um olhar sobre a educação do campo a partir do Projeto Magistério da Terra Polo Tucuruí. In G. P. Silva, H. H. B., Canali, D. S., Rodrigues, \& M. N. C. Araújo (Org.), Educação do campo na Amazônia: Uma experiência (pp. 115-122). Belém: EDUFPA.

UNESCO (2013). Global Media and Information Literacy Assessment Framework: Country Readiness and Competencies (158 p). Paris. http://unesdoc.unesco.org/images/0022/002246/224655e.pdf

United Nations (2015). Quality Education. In 17 Goals to Transform Our World. New York, NY. https://www.un.org/sustainabledevelopment/education/

Universidade Estadual de Campinas. Centro Nacional de Processamento de Alto Desempenho (2016). SAS Programação I: Introdução ao SAS (125 p). Campinas.

https://www.cenapad.unicamp.br/servicos/treinamentos/apostilas/apostila_sas.pdf

Vasconcelos, M. E. O. (2017). Educação do campo no Amazonas: História e diálogos com as territorialidades das águas, das terras e das florestas. Doctoral Thesis, Belém, PA: Universidade Federal do Pará.

Vizolli, I., Aires, H. Q. P., \& Barreto, M. G. (2018). A Pedagogia da Alternância presente nos Projetos Político-Pedagógicos das Escolas Famílias Agrícolas do Tocantins. Educação e Pesquisa, 44, e166920.

http://www.scielo.br/pdf/ep/v44/1517-9702-ep-44-e166920.pdf

https://doi.org/10.1590/s1678-4634201844166920

Zimmermann, A., Venduscolo, R., \& Dorneles, S. B. (2013). Educação do campo: O processo de implementação da Casa Familiar Rural do Vale do Jaguari (CFV/VJ). Geografia Ensino \& Pesquisa, 17, 79-90. https://doi.org/10.5902/2236499412493 